\title{
Pemberdayaan Masyarakat Melalui Kesadaran Hukum Fungsi Administrasi, Fungsi Penatagunaan Tanah Di Dusum Balong Dan Dusun Petung Desa Wates, Kecamatan Dukun, Kabupaten Magelang, Jawa Tengah
}

\author{
Sunarno1) , Putri Anggia, Nanda \\ ${ }^{12)}$ Program Studi Hukum, Fakultas Hukum, Universitas Muhammadiyah Yogyakarta \\ Email: sunarno@umy.ac.id \\ Jl. Brawijaya, Tamantirto, Kasihan, Bantul, Yogyakarta 55183 \\ DOI: 10.18196/ppm.31.149
}

\begin{abstract}
Abstrak
Kesadaran hukum masyarakat akan penggunaan tanah untuk berbagai sektor secara benar akan memengaruhi capaian kesejahteraan ekonomi disamping mendapatkan tertib administrasi. Namun kenyataannya tingkat kesadaran hukum masyarakat masih di bawah rata rata dan belum tertib sehingga antara satu kelompok kepentingan dengan kelompok lain tidak berjalan secara harmonis. Contoh nyata adalah penggunaan tanah untuk perikanan satu sisi dan di sisi lain kelompok tertentu masih bertahan untuk kepentingan pertanian dan perkebunan sehingga timbul disharmoni mengenai penggunaan air. Oleh karena itu pengabdian KKNPPM ini bermitra dengan Kelompok kelompok Masyarakat Dusun Petung Desa Wates untuk menjawab permasalahan berupa tuntutan peningkatan kesadaran hukum tentang penggunaan tanah yang baik dan haromnis berupa: 1. memperkuat pemahaman artinya pentingnya penggunaan tanah yang baik menurut peraturan perundang-undangan agraria; 2 . Memberikan kesepahaman antar kelompok masyarakat dalam penggunaan tanah dalam sektor yang berbeda dengan menuangkan kesepahaman dalam peraturan dusun yang memuat ketentuan ketentuan harmonisasi berbagai kelompok masyarakat dalam penggunaan tanah, hasil akhir dari pengabdian ini adalah diterapkan iptek di dusun mitra oleh kelompok perikanan, petani padi, petani salak di Dusun Petung. Target luaran dari program ini adalah publikasi dijurnal akreditasi dan mencetak buku saku penyelesaian sengketa Pemberdayaan masyarakat, Kesadaran hukum, fungsi Administrasi, fungsi penatagunaan tanah Win win solution.
\end{abstract}

Kata Kunci: Kesadaran Hukum, Fungsi Penataguaan, Tanah

\section{Pendahuluan}

Pengabdian kepada masyarakat termasuk juga melalui Kuliah Kerja Nyata (KKN) merupakan bentuk pengabdian yang nyata civitas akademika baik dosen maupun mahasiswa kepada masyarakat yang sebenarnya dengan cara menyalurkan ilmu yang sudah didapat di perkuliahan guna untuk membantu menerapkan di lingkungan masyarakat. Tujuan pelaksanaan pengabdian dan KKN ini yakni membangun karakter mahasiswa yang secara langsung terlibat dalam kegiatan masyarakat serta mengembangkan keilmuan sosial dan mahasiswa mampu untuk turut membantu dalam memecahkan problematika yang dihadapi oleh masyarakat desa. Khusunya di Desa Wates di Dusun Petung dan Dusun Balong.

Desa Wates memiliki letak geografi dengan luas bujur 110.3445, dan kordinat lintang 559.789. Batas wilayah Desa Wates di sebelah utara dengan Desa Dukun, disebelah timur dengan Kalibening, disebelah barat dengan Kiatunggeng, dan disebelah selatan dengan Pandan Retno. Desa Wates memiliki luas wilayah 183.526 Ha. Jarak Desa Wates dengan kabupaten 20 
Km. Kondisi lahan, di mana luas wilayah penggunaan lahan $134.49 \mathrm{Ha}$, tanah kering seluas 40 Ha. Perekonomian di desa tersebut masih bergantung pada pertanian terutama sawah sebagai tadah hujan. Hak-hak atas tanah baik individu maupun hak masyarakat atas tanah merupakan permasalahan yang perlu untuk di berikan jawabannya.

Dusun Petung merupakan salah satu dusun berpenduduk terbesar dari 10 dusun. Penduduk Dusun Petung terdiri dari $100 \mathrm{KK}$, Kelurahan Wates sendiri terdiri dari $12 \mathrm{RW}$ dan 80 RT dengan jumlah penduduk \pm 8.320 jiwa (data s/d bulan Desember 2015) dan luas wilayah 119,40 Ha.

Dusun Petung adalah dusun terpadat yang meliputi $112 \mathrm{KK}$ dengan luas 2,7 km2, jumlah penduduk 330, laki laki 173 sedangkan perempuan 157.

Batas wilayah
a. Utara
: Sungai Lamat
b. Timur
: Desa Kali Bening
c. Selatan
: Sungai Ingas
d. Barat
: Dusun Selosari

Dusun Petung secara umum dihuni masyarakat bermata pencaharian sebagai petani tradisional dengan bertanam berbagai jenis tanaman seperti salak, padi, cabai, dan sayur mayur. Sekarang ini, Desa Petung sedang mengembangkan perikanan dan peternakan walaupun masih sekala individual.

Secara umum posisi Dusun Petung merupakan daerah pinggiran kota sebagaimana dapat dilihat dipeta dibawah ini.

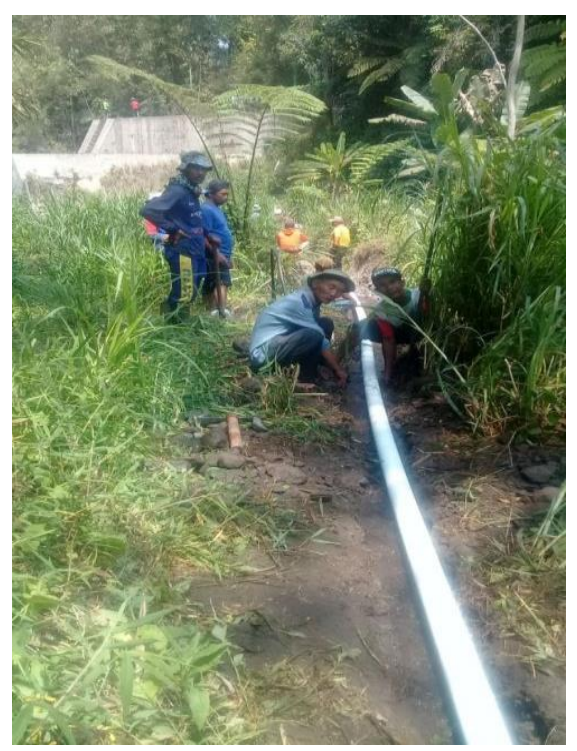


Masyarakat dusun Petung masih menjunjung tinggi komunalitas di mana kepentingan umum dan sosial dijunjung tinggi diatas kepentingan pribadi. Gambar di atas menggambarkan pembuatan saluran air untuk kepentingan masyarakat disepakati melalui tanah tanah individual demi terwujudnya kepentingan umum dan sosial.

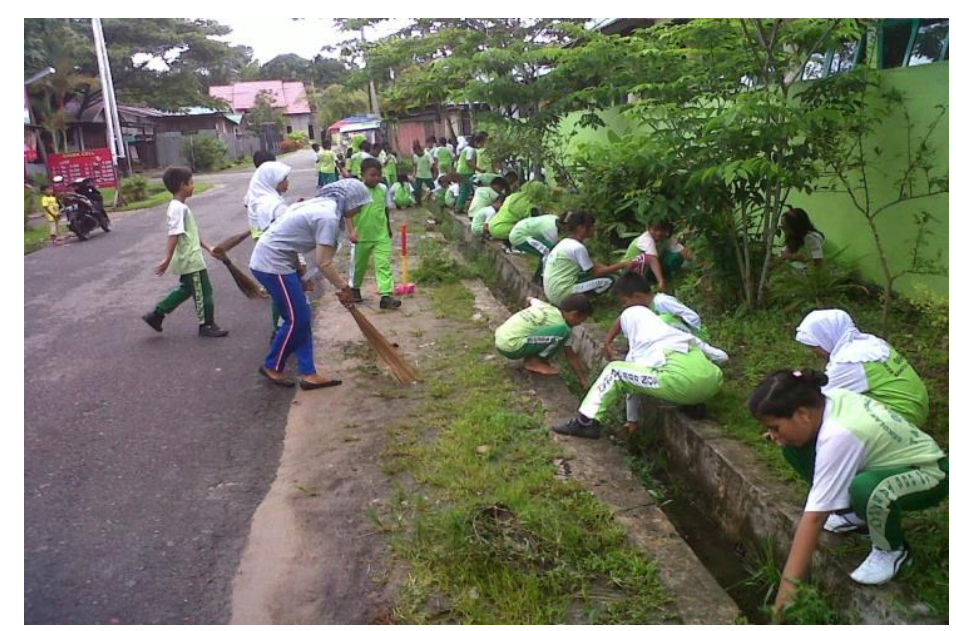

Nilai komulitas dalam menjaga kepentingan umum maupun sosial merupakan modal sosial masyarakat dalam mengendalikan maupun menyelesaian berbagai sengketa tanah.

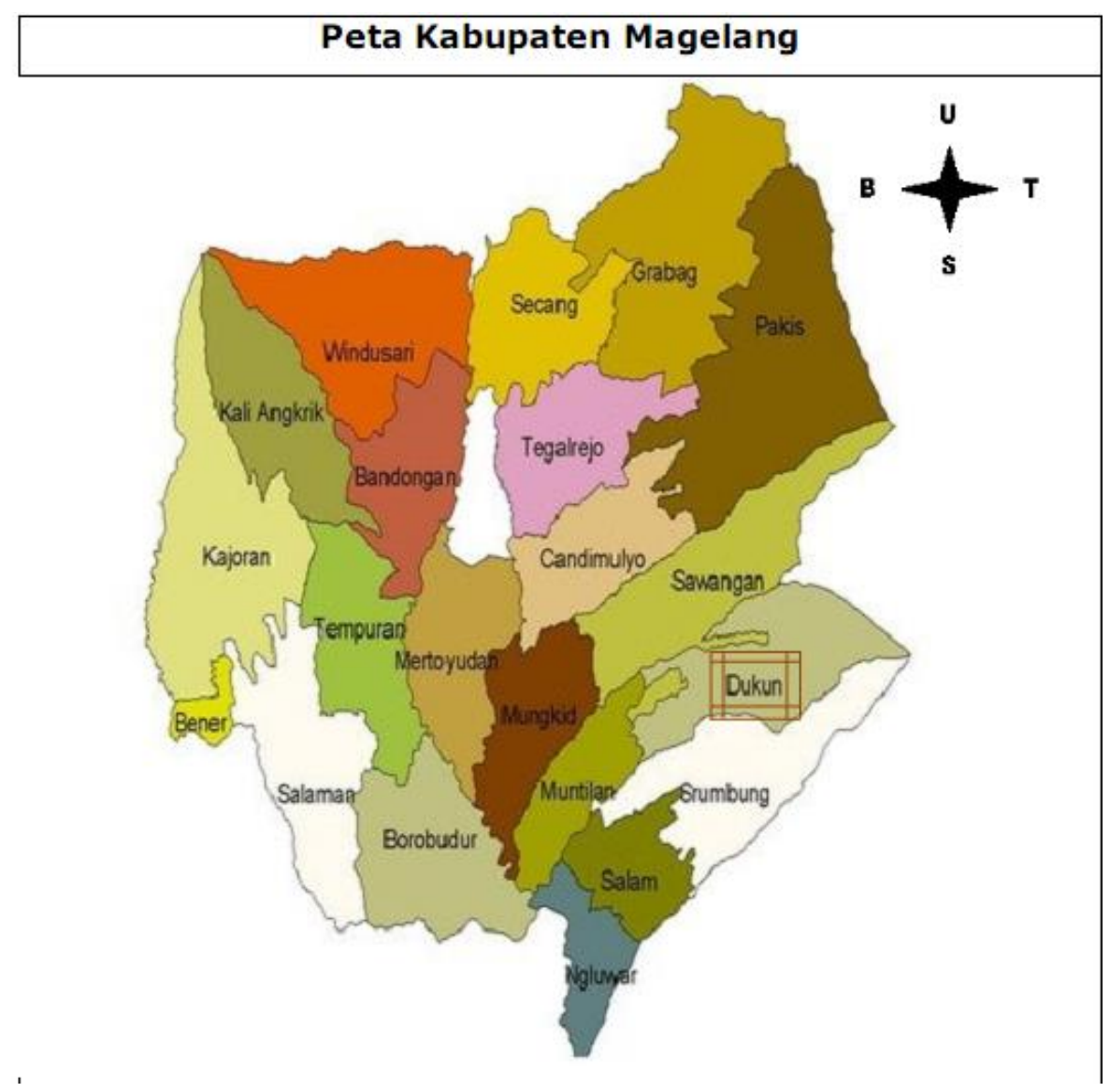


Sementara itu, karakter tanah yang merupakan faktor sumber kehidupan yang terbatas jumlahnya sementara kepentingan diberbagai sektor kehidupan yang sangat akseleratif sehingga menimbulkan banyak benturan kepentingan, telah pula melahirkan sifat-sifat emosional manusia yang paling ekstrem yakni berbagai kejahatan kemanusiaan yaitu menghilangkan nyawa tanpa merasa berdosa. Gambaran emosional tersebut direfleksikan dalam kata yang berlaku di Jawa yaitu se dumuk batuk, se nyari bumi, senajan pati den tohi

Sengketa tanah yang di dalamnya terlibat tidak hanya aspek tanah secara fisik, namun beberapa aspek lain pun masuk di dalamnya misalnya, aspek keyakinan (sehingga dijawa ada istilah tanah pusaka atau heirloom land, yang dalam tradisi jawa pantang untuk dipindahkan kepada orang lain yang bukan keluarganya), aspek ras yang dalam peraturan di Indonesia pun diakui tentang tidak boleh ada kepemilikan tanah oleh warga negara asing, dan aspek-aspek lainnya yang semakin menambah rumit persoalan tanah yang ada (Suhendar, 1997: 46).

Pengadilan yang di dalamnya ada sistem beracara yang lebih terbuka dan frontal dipandang masyarakat terlalu birokratis dan legalistik fomalistik sehingga relatif tidak efektif untuk memecahkan sengketa-sengketa tanah. Di samping pandangan bahwa hasilnya banyak hal tidak adil setidaknya bagi pihak yang dikalahkan, juga tidak menawarkan win-win solution, sehingga permasahan yang diajukan tidak mendapatkan pemecahan yang tuntas (Maria, 2001:57)

Oleh karena itulah, banyak masyarakat pedesaan atau bahkan mungkin perkotaan lebih memilih pemecahan sengketa tanah melalui jalur di luar pengadilan yaitu melalui musyawarah oleh kedua belah pihak yang bersengketa yang dibimbing oleh juru penengah/mediator yang dipercaya. Kepala Desa, Kepala Dusun, atau sesepuh masyarakat biasanya yang mempunyai pengetahuan tentang sejarah dan kaedah-kaedah pertanahan di desa di mana tanah sengketa terletak, dipercaya oleh pihak bersengketa sebagai mediator. Mediasi yang demikian itu dalam bahasa modernnya dikenal sebagai model Alternatif Dispute Resolution (ADR)

Penataan dan sosialisasi pemecahan sengketa tanah melalui ADR yang hidup di desa-desa ataupun dusun-dusun sangat membantu kinerja penegakan hukum dibidang pertanahan di samping pengadilan yang ada. 
Tindak lanjut dari penelitian pada tahun 2000 di beberapa kecamatan di Indonesia dan hasil penelitian yang dibiayai DIKTI oleh Pengusul, yang menyimpulkan bahwa:

1. Pada praktiknya, sebagian besar sengketa tanah di pedesaan diselesaikan melalui jalur diluar pengadilan, yang dilakukan melalui bantuan juru damai/penengah yaitu tokoh-tokoh masyarakat dari kalangan pada kepala dusun, tokoh agama, tokoh sosial, dan para kepala desa;

2. Faktor yang menjadi alasan menunjuk jalur di pengadilan karena sistem pengadilan kurang mendapat kepercayaan masyarakat, biaya terlalu besar, waktu yang terlalu lama, kaidah beracara yang rumit dan konfrontatif;

Lebih lanjut di dalam penelitian tersebut terdapat saran bahwa kepercayaan yang besar dari masyarakat kepada para juru damai tersebut tidak diimbangi oleh sistem pembinaan kemampuan juru damai oleh pemerintah. Sehingga beban yang dialami oleh para juru damai cenderung overload secara kuantitas maupun kualitas. Idealnya bahwa kepercayaan masyarakat yang besar tersebut harus diimbangi oleh kebijakan pemerintah di dalam mendidik dan mengembangkan kemampuan para juru damai berupa dengan wawasan mengenai hukum tanah, keterampilan modern mengenai penyelesaian sengketa, begitu pula manajemen adminitrasi penyelesaian sengketa tanah.

Sementara itu, karena hampir setiap tingkat dusun banyak sengketa tanah sebagaimana hasil penelitian menunjukkan 10 kasus tanah untuk setiap dusun maka urgensi kemampuan menyelesaikan sengketa tanah menjadi suatu keniscayaan untuk selalu ditingkatkan.

Terdapat beberapa alasan mendasar mengapa memilih Desa Wates Kecamatan Dukun, Magelang:

1. Desa-desa di kecamatan tersebut merupakan kawasan sasaran pengembangan kota (hinterland) sehingga kegiatan yang langsung berkait dengan tanah sangat memungkinkan menjadikan banyaknya benturan kepentingan yang pada akhirnya akan menimbulkan sengketa tanah;

2. Desa - desa di kecamatan ini memiliki tanah yang sebagian besarnya belum bersertifikat, hal ini menambah rumitnya permasalahan tanah.

3. Banyaknya tokoh-tokoh masyarakat baik tokoh formal maupun informal yang dipercaya untuk menyelesaikan sengketa tanah dari 410 kasus sengketa tanah yang masuk ke jalur pengadilan hanya 11 kasus, selebihnya dipercayakan penyelesaiannya kepada Kepala Desa ataupu tokoh-tokoh masyarakat; 
4. Di antara desa-desa di Kecamatan, Desa Wates memiliki paling banyak sengketa tanah baik ditinjau secara kuantitatif maupun jenisnya.

5. Desa tersebut memiliki jenis-jenis hak atas tanah yang lebih kompleks, misalnya terdapat banyak tanah Sultanground yang sering menjadi sengketa.

Lurah dan perangkat kelurahan semunya, secara normatif berkewajiban melayani masyarakat demikian harus berkapasitas untuk menjadi juru penengah masyarakat apabila ada sengketa antarwarga.

Berdasarkan gambaran situasi tersebut, menjadi argumentasi kuat bahwa peningkatan kemampuan juru damai dalam menyelesaikan sengketa tanah sangat perlu ditingkatkan.

\section{PERMASALAHAN KELOMPOK MITRA}

Berdasarkan analisis situasi tersebut tergambar jelas permaasalahan kelompok masyarakat mitra yaitu:

1. Masyarakat dusun petung masih kurang terhadap pemahamannya mengenai makna tanah dan fungsi-fungsi pengaturan pertanahan,

2. Masih banyaknya tumpang tindih penggunaan tanah yang menimbulkan kerugian dan rendahnya produktivitas pertanahan;

Pelaksanaan penyelesaiaan sengketa pertanahaan di Indonesia menurut Undang-Undang No. 5 Tahun 1960 adalah salah satu tujuan penyelesaiaan suatu permasalahan terutama sengketa pertanahan adalah untuk memperoleh jaminan adanya kepastian hukum bagi seluruh pihak yang terlibat dalam suatu persengketaan.

Sengketa tanah dapat berupa sengketa administratif, sengketa perdata, sengketa pidana terkait dengan pemilikan. Suatu sengketa tanah subjeknya tidak hanya satu, namun lebih dari satu, entah itu antara individu, kelompok, organisasi bahkan lembaga besar sekalipun seperti badan usaha milik negara (BUMN) ataupun negara. Status hukum antara subjek sengketa dengan tanah yang menjadi objek sengketa bisa berupa pemilik, pemegang hak tanggungan, pembeli, penerima hak, penyewa, pengelola, penggarap, dan sebagainya. Sedangkan objek sengketa tanah meliputi tanah milik perorangan atau badan hukum, tanah aset negara atau pemda, tanah negara, tanah adat dan ulayat, tanah hak nasional, tanah perkebunan, serta jenis kepemilikan lainnya

\section{Metode Pelaksanaan}


Permasalahan berupa tuntutan peningkatan kapasitas untuk menyelesaian sengketa berupa: 1 . memperkuat pemahaman makna tanah dan faktor fundamental adanya sengketa; 2. memberian pelatihan untuk mencapai skill penyelesaian sengketa melalui ADR; dan 3. Pengembangan sistem kerja kelembagaan penyelesaian sengketa tanah. Hasil akhir dari pengabdian ini adalah diterapkan iptek di desa mitra oleh penjabat perangkat desa berupa kemampuan menyelesaian sengketa yang timbul dengan upaya damai dan harmonis ditingkat masyarakat setempat

Jadi terdapat kesenjangan hebat yaitu, satu sisi menjukkan tingginya kepercayaan masyarakat kepada juru damai untuk penyelesaian sengketa tanah lewat jalur damai di luar pengadilan di pedesaan, sisi lain tidak ada keberpihakan yang berarti dari berbagai kebijakan pemerintah untuk membina dan meningkatkan keterampilan juru damai dalam menyelesaikan sengketa tanah, sementara sengketa tanah dari hari ke hari semakin banyak dan komplek:

1. Peningkatan wawasan hukum pertanahan harus dilakukan sehingga kelompok masyarakat mitra Dusun Petung mempunyai pengetahuan standar mengenai fungsi fungsi pengaturan pertanahan melalui solusi penyuluhan dan konseling pertanahan.

2. Peningkatan keterampilan berbagai model penyelesaian sengketa tumpang tindih fungsi pengaturan tanah bagi kelompok masyarakat melalui solusi pelatihan dan workshop

\section{Pertanahan.}

a. Untuk mencapai tujuan angka 1 dicapai dengan melakukan penyuluhan hukum dan prinsipprinsip manajemen dengan pendekatan holistik.

b. Untuk mencapai tujuan angka 2 dan 3 perlu dilakukan kegiatan dalam bentuk pelatihan, dan simulasi penyelesaian sengketa;

Partisipasi masyarakat ditarik dengan cara diundang oleh panitia kelompok masyarakat itu sendiri dan dibuat undangan yang menarik yang dirancang oleh panitia kelompok masyarakat tersebut. 
Keaktifan kegiatan oleh peserta penyuluhan dan pelatihan sangat penting, oleh karenanya forum dilaksanakan dengan dialogis dan instrument yang simple dan lengkap

Kegiatan secara umum dilaksanakan dalam dua klaster yaitu penyuluhan dan pelatihan sebagai rangkaian yang tak terpisahkan.

\section{GAMBARAN IPTEK}

Undang Undang Pokok Agraria Nomor 5 tahun 1960 tentang Peraturan dasar pokok pokok agraria meletakan dasar pengaturan Pertanahan menjadikan makna tanah mempunyai beberapa berbagai penggunaan. Oleh karena itu mengatur lebih lanjut macam macam penggunaan tanah dengan dasar hukum:

\section{Pasal 2 UUPA}

\section{Pasal 14}

\section{Pasal 15}

Pasal 2 menegaskan kewenangan negara untuk mengatur peruntukan tanah untuk berbagai keperluan termasuk arti penting keharomisan penggunaan antarkepentingan yang berbeda. Kemudian Pasal 14 menegaskan berbagai jenis alokasi penggunaan tanah untuk berbagai kepentingan baik untuk kepentingan umum maupun kepentingan individual dengan berbagai aspeknya.

Sedangkan Pasal 15 menegaskan bahwa setiap individu harus memelihara kesuburan tanah, menjaga agar tidak rusak termasuk penggunaan yang tidak boleh mengganggu kepentingan orang lain.

Lebih lanjut mengenai alokasi pengunaan tanah tan prinsip tertib harmonisnya diatur lebih rinci dalam Peraturan perundang undangan terkait yaitu

- UU Tata Ruang 26/2007

- UU Koservasi Tanah Pertanian Berkelanjutan

- UU Kebencanaan UU No 24/2007

- Undang Undang Propenas 
Gambaran iptek berisi uraian maksimal 500 kata menjelaskan gambaran iptek yang akan diimplentasikan di mitra sasaran.

- Peraturan ditingkat bawahnya

Dampak dari penggunaan yang tidak harmonis dan tidak tertib maka penggunan tanah akan berpotensi menimbulkan

- Banjir

- Macet

- Munculnya pemukiman kumuh

- Munculnya masyarakat pinggiran

- Pengangguran

- Krisis pangan dan air

- Kerugian ekonomi lainya secara luas.

Pedoman pedoman dalam pengguna tanah harus mengacu pada:

- Rencana Penatagunaan tanah (tata ruang) nasional

- Rencana Penatagunaan tanah (tata ruang) propinsi

- Rencana Penatagunaan tanah (tata ruang) kabupaten

- Rencana detail penatagunaan tanah (ruang) pada semua tingkatan pemerintahan.

Untuk secara detail masyarakat dapat menjabarkan kehormanisan dalam instrumen hukum di pemerintahan terbawah atau dalam hukum hukum kebiasaan yang sesuai dengan peraturan nasional.

Sedangkan prinsip tata guna tanah untuk mencapai fungsi yang maksimal maka peraturan memberikan guideline sebagai berikut:

- Harmonis

- Berkelanjutan

- Terbuka 
- Terpadu Adil

\section{Pelaksanaan Program}

\section{Penyuluhan dan konseling tertib penggunaan pertanahan}

Metode pelaksanaan program kerja Penyuluhan dan Workshop Pemberdayaan Masyarakat Melalui Peningkatan Hukum Pertanahan dibagi menjadi 2 waktu karena letak antara Dusun Balong dan Dusun Petung terbilang lumayan cukup jauh, Pelaksanaan Program diawali dengan pelaksanaan di Dusun Balong pada tanggal 15 Januari 2020 pada jam 16.00-17.30 WIB bertempat di salah satu rumah warga Dusun Balong. Sosialisasi ini dihadiri sekitar 20 warga Dusun Balong. Sedangkan Pelaksanaan Program kerja Penyuluhan dan Workshop Pemberdayaan Masyarakat Melalui Peningkatan Hukum Pertanahan yang dilaksanakan di Dusun Petung dilaksanakan pada tanggal 22 Januari 2020 pada pukul 16.00-17.30 WIB bertempat di halaman Masjid Dusun Petung dan dihadiri sekitar kurang lebih 30 warga Dusun Petung.

Sengketa antara masyarakat dengan masyarakat dapat disebabkan salah satunya permasalahan atas tanah yang bersengketa dengan munculnya dualisme sertifikat atau tumpang tindihnya kepemilikan atas tanah. Sengketa antara masyarakat dengan pemerintah yang pertama yaitu tentang kepemilikan tanah dalam perbedaan persepsi mengenai konsep penguasaan dan pemanfaatan tanah. ${ }^{1}$ Hal ini telah diatur dan ditetapkan dalam Pasal 19 ayat (1) UUPA tentang Pendaftaran Tanah yang menyatakan bahwa: "untuk menjamin kepastian hukum oleh Pemerintah diadakan Pendaftaran Tanah diseluruh wilayah Republik Indonesia menurut ketentuan-ketentuan yang diatur dengan Peraturan Pemerintah.,"2

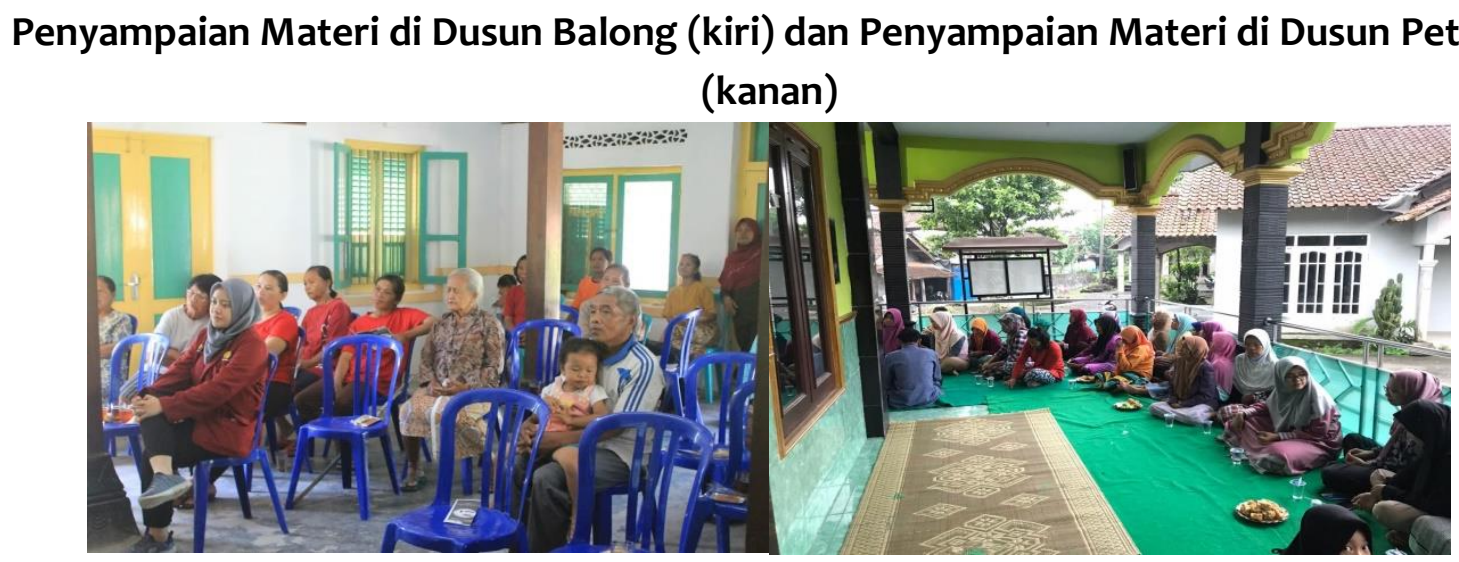

\footnotetext{
${ }^{1}$ Herlina Ratna Sambawa Ningrum, "Analisis Hukum Sistem Penyelesaian Sengketa Atas Tahan Berbasis Keadilan”, Jurnal Pembaharuan Hukum Vol 1 No. 2, 2014, hal 219-220.

${ }^{2}$ Pasal 19 Ayat (1) Undang-Undang Republik Indonesia Nomor 5 Tahun 1960 Tentang Peraturan Dasar PokokPokok Agraria.
} 


\section{Sumber: Dokumen Penulis}

Melalui penyampaian materi ini berharap warga dapat mengetahui bagaimana penerapan hukum dalam pertanahan. Selain itu juga dapat berbagi dalam menyampaikan ilmu sehingga masyarakat memahami bagaimana prosesnya dan juga bagaimana cara penyelesaiannya. Dengan ini masyarakat lebih taat akan adanya hukum yang berlaku di Indonesia.

\section{Pelatihan dan Workshop Pertanahan}

Pelatihan dan workshop pertanahan ini dibuka dengan sambutan oleh Bapak Kepala Dusun yaitu Bapak Taryono dan Ketua Pelaksana sosialisasi ini. Kemudian dilanjutkan dengan pengisian materi tentang Pendaftaran Tanah terlebih dahulu. Pendaftaran Tanah adalah serangkaian kegiatan yang dilakukan oleh Pemerintah secara terus menerus, berkesinambungan, dan teratur, meliputi pengumpulan, pengolahan, pembukuan dan penyajian serta pemeliharaan data fisik maupun data yuridis dalam bentuk peta dan daftar, mengenai bidang-bidang tanah atau rumah susun,sermasuk pemberian sertifikat sebagai tanda bukti. Tujuan dari pendaftaran tanah adalah untuk memberikan kepastian hukum dan perlindungan hukup kepada pemegang hak atas tanah sehingga menimbulkan rasa mantap dan rasa aman mengenai kepastian hukumnya,kepastian mengenai tanah yang di haki, dan adanya perlindungan hukum untuk mencegah gangguan dari penguasaan dan/atau sesama warga masyarakat. ${ }^{3}$

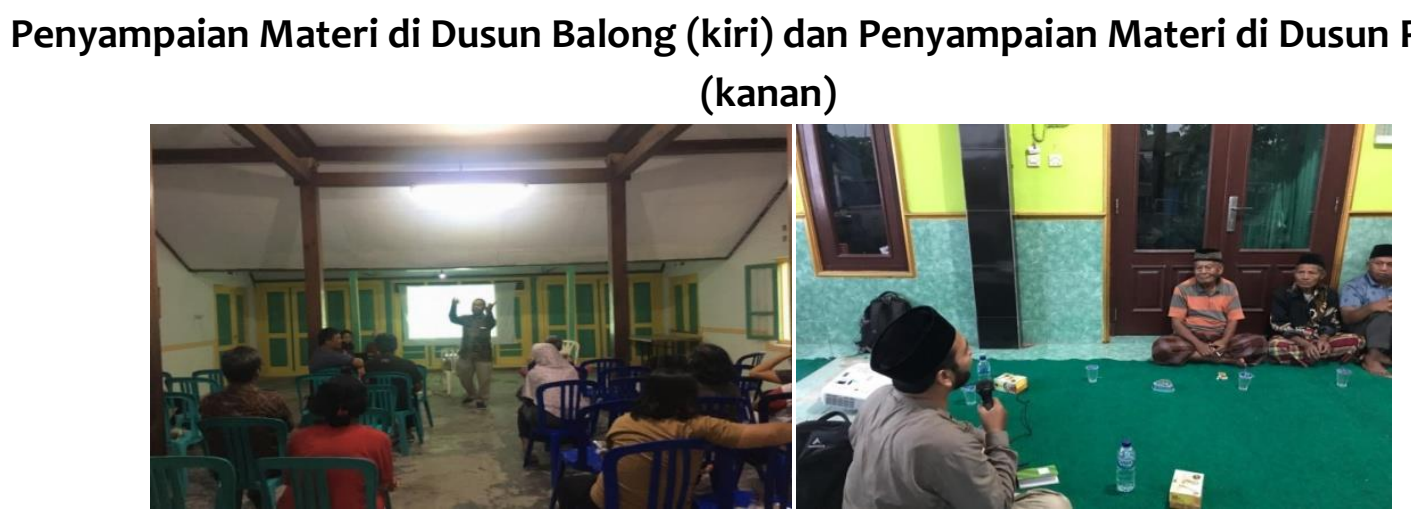

Sumber: Dokumen Penulis

Di materi ini diharapkan masyarakat warga Balong dapat memahami hak atas tanah, serta untuk mewujudkan tertib informasi bagi masyarakat yang membutuhkan. Pada materi ini dijelaskan bagaimana penerapan sistem pendaftaran tanah yang terbagi menjadi:

1. Pengumpulan dan pengelolaan data fisik

2. Pengumpulan dan pengelolaan data yuridis serta pembukuannya, dalam data yuridis untuk hak tanah baru dibuktikan dengan penetapan pemberian hak dan asli akta PPAT yang memuat peralihan hak atas tanah, hak pengelolaan dibuktikan dengan pemberiaan

\footnotetext{
${ }^{3}$ Aartje Tehupeiory, Pentingnya Pendaftaran Tanah di Indonesia, Depok: Raih Asa Sukses, 2012, hal.2
} 
hak pengelolaan, tanah wakaf dibuktikan dengan Akta PPAIW ,Hak atas satuan rumah susun dibuktikan dengan akta pemisahan, hak tanggungan dibuktikan dengan akta pemberian hak tanggungan.

3. Penerbitan sertifikat, sertifikat disini merupakan kumpulan surat ukur yang memuat data fisik dan buku tanah yang memuat data yuridis yang diberi sampul dan disahkan oleh pejabat yang berwenang.

4. Penyajian data fisik dan data yuridis. Untuk pembuktian data yuridis dibuktikan dengan

- gross akta eigendom berdasar Ordonasi maupun Statblad

- surat hak milik yang diberikan pemerintah swapraja

- sertifikat hak milik berdasar PP 9 tahun 1959

- akta pemindahan hak dibawah tangan

- akta pemindahan hak yang dibuat PPAT

- akta ikrar wakaf

- surat penunjukan atau pembeluan tanah kavling

- petuk pajak bumi, girik, pipil,ketikir, verponding indinesia sebelum berlakunya PP no 10 tahun 1961

- lain-lain bentuk alat bukti tertulis

5. Penyimpanan daftar umum dan dokumen

Sedangkan untuk syarat-syarat permohonan untuk mengajukan pendaftaran tanah antara lain

1. Jelas identitas subjek pemilik sebagai pemohon dengan menunjukan KTP, C1, dan Identitas yang diperlukan

2. Jelas objek yang dimohonkan meliputi data fisik yang menyangkut batas tanah luas, lebar, bentuk tanah, keadaan diatasnya, pengakuan dari saksi yang berkopeten, juga jelas data yuridis yaitu menyangkut kepemilikan tanahnya baik dibuktikan dengan bukti tertulis maupun saksi atau setidaknya pernyataan hak ditambah surat keterangan dari pejabat yang berwenang.

Sertifikat tanah menjadi bukti kepemilikan atau penguasaan seseorang atas tanah. Pasal 4 ayat (1) UUPA menjamin hak dari setiap pemegang hak atas tanah untuk memperoleh sertifikat. Fungsi utama dan terutama dari sertifikatadalah bukti kepemilikan hak atas tanah yang sah dan kuat. ${ }^{4}$ Setelah mengajukan pendaftaran maka akan mendapatkan sertifikat yang merupakan hasil dari pendaftaran tanah bagi warga masyarakat yang telah memenuhi syarat baik menyangkut data fisik maupun tertulisnya,sebagai tanda bukti yang sah bahwa tanah tersebut telah terdaftar.

\section{Penyampaian Materi}

${ }^{4}$ Christiana sri Murni, "Peralihan Hak Atas Tanah Tanpa Sertifikat”, Jurnal Ilmu Hukum: Vol 4 No. 2, 2018, Hal 681. 


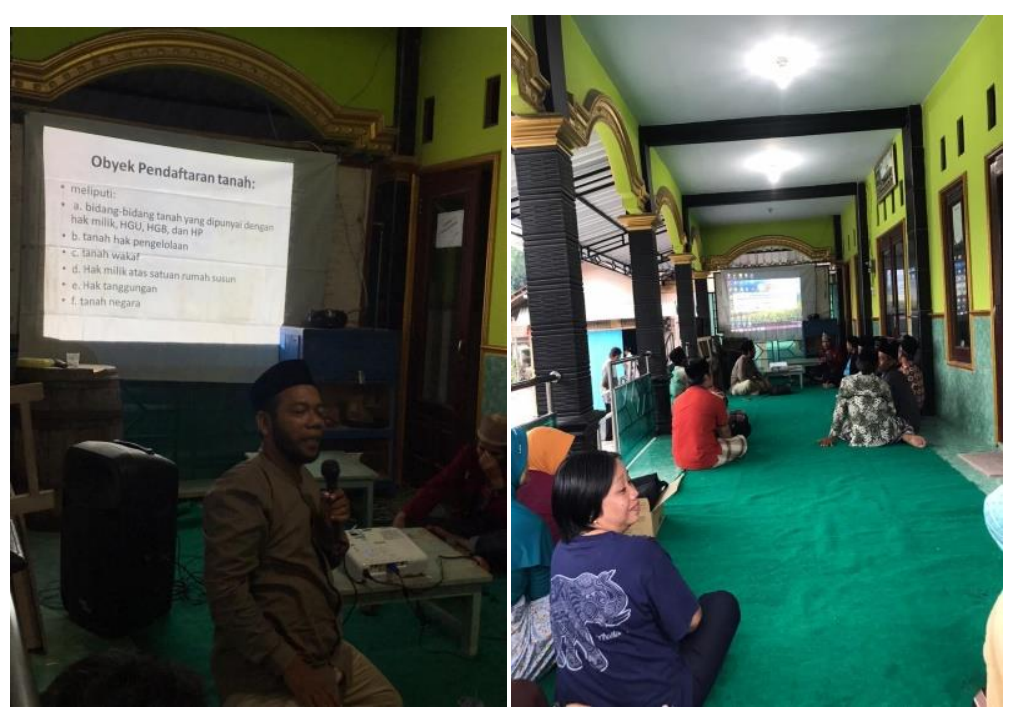

Sumber: Dokumen Penulis

Penyampaian Materi di Dusun Balong (kiri) dan Penyampaian Materi di Dusun Petung (kanan)

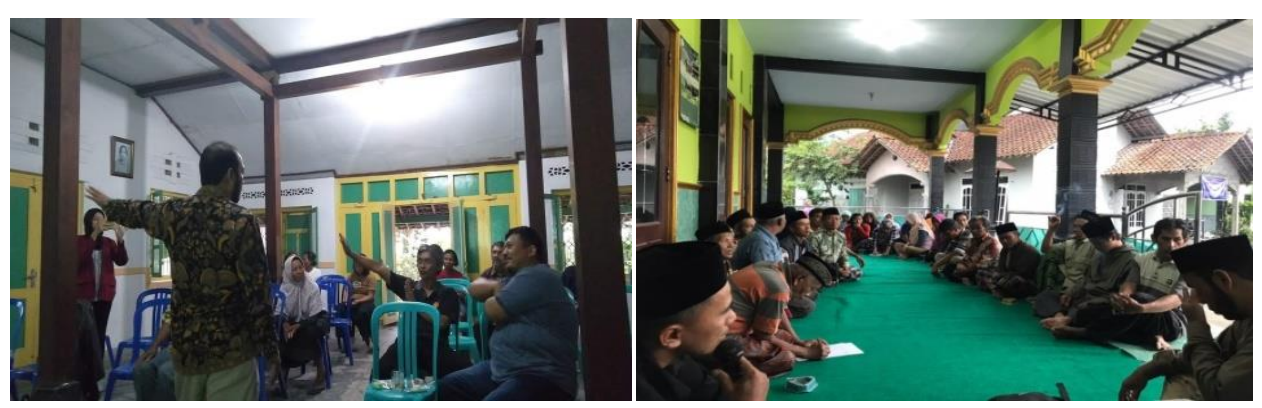

\section{Sumber: Dokumen Penulis}

Untuk selanjutnya penyampaian materi yang kedua tentang bagaimana Kebijakan Penyelesaian dalam Sengketa Tanah. Dalam materi ini dijelaskan bahwa terdapat beberapa cara dalam penyelesaian sengketa tanah yaitu dengan cara litigasi melalui konsultasi hukum, negosiasi atau melibatkan dua atau lebih pihak yang berkepentingan. Tujuannya, agar tercapai suatu kesepakatan, ataupun menggunakan Mediasi, yaitu adalah penyelesaian sengketa dengan menengahi,Konsiliasi yang dapat diartikan sebagai usaha mempertemukan keinginan pihak yang berselisih agar mereka sepakat menyelesaikan masalah ${ }^{5}$ ataupun Arbitrase maupun Non-Litigasi yang dapat dilaksanakan melalui peradilan Pidana, Perdata, administrasi Negara, ataupun Agama.

\footnotetext{
${ }^{5}$ Elza Syarief, Menuntaskan Sengketa Tanah Melalui Pengadilan Khusus Pertanahan, Jakarta: KPG(Kepustakaan Populer Gramedia), 2012, Hal 247-249.
} 


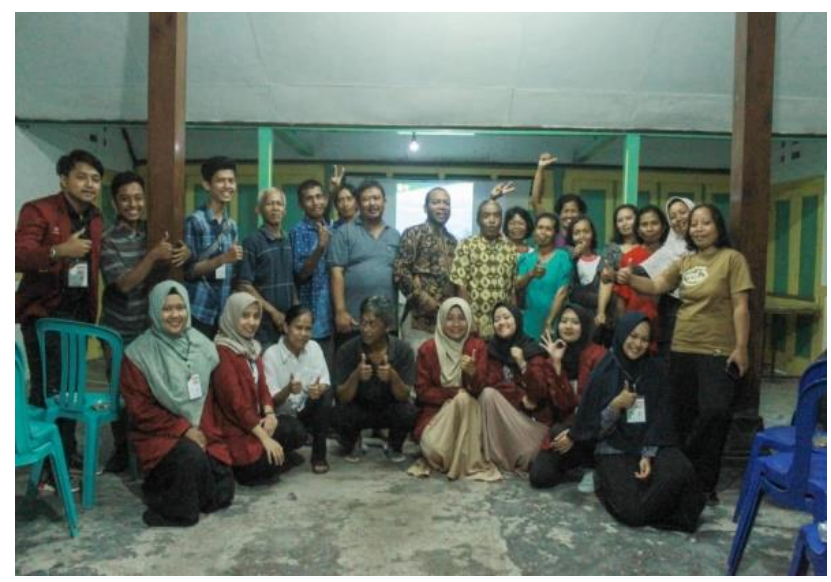

Sumber: Dokumen Penulis

\section{JADWAL}

\begin{tabular}{|c|c|c|c|c|c|c|c|c|c|c|c|c|c|}
\hline \multirow{2}{*}{ No } & \multirow{2}{*}{ Nama Kegiatan } & \multicolumn{12}{|c|}{ Minggu } \\
\hline & & 1 & 2 & 3 & 4 & 5 & 6 & 7 & 8 & 9 & 10 & 11 & 12 \\
\hline 1 & $\begin{array}{l}\text { Merancang } \\
\text { Proposal }\end{array}$ & & & & & & & & & & & & \\
\hline 2 & Perijinan & & & & & & & & & & & & \\
\hline 3 & $\begin{array}{l}\text { Kegiatan inti 1, } \\
\text { Penyuluhan dll }\end{array}$ & & & & & & & & & & & & \\
\hline 4 & $\begin{array}{l}\text { Kegiatan Inti 2, } \\
\text { Pelatihan dll }\end{array}$ & & & & & & & & & & & & \\
\hline 5 & $\begin{array}{l}\text { Kegiatan Inti 3, } \\
\text { Management } \\
\text { Organisasi }\end{array}$ & & & & & & & & & & & & \\
\hline 6 & $\begin{array}{l}\text { Penyerahan } \\
\text { Hibah dan } \\
\text { Laporan }\end{array}$ & & & & & & & & & & & & \\
\hline
\end{tabular}

\section{Simpulan}

Hasil dari Pelaksanaan Program KKN yang bertemakan Penyelesaian Sengketa Tanah dengan metode sosialisasi telah berhasil walaupun belum maksimal karena terdapat kendala durasi waktu yang terbatas. Meskipun demikian,permberdayaan masyarakat dan memberikan edukasi dan pengetahuan tambahan kepada masyarakat Desa Wates terutama Dusun Balong dan 
Dusun Petung tentang pentingnya penyelesaian sengketa tanah melalui media hukum dapat tersampaikan.

\section{Saran}

Seharusnya Pelaksanaan Program Penyelesaian Sengketa Tanah yang melalui metode sosialisasi dapat diberikan durasi waktu yang lebih panjang sehingga masyarakat dapat memperoleh informasi yang lebih lengkap.

\section{Ucapan Terimakasih}

Terimakasih kami ucapkan kepada:

Warga Masyarakat Dusun Balong dan Dusun Petung Desa Wates Kecamatan Dukun, Kabupaten Magelang, Jawa Tengah.

\section{Daftar Pustaka}

\section{Buku}

Endang Darusman, Reformasi Agraria

Maria Sumardjono, Pertanahan, dari Regulasi ke Implementasi

Syarief, E. (2012). Menuntaskan Sengketa Tanah Melalui Pengadilan Khusus Pertanahan. Jakarta: KPG (Kepustakaan Populer Gramedia).

Tehupeiory, A. (2012). Pentingnya Pendaftaran Tanah di Indonesia. Depok: Raih Asa Sukses.

\section{Jurnal}

Murni, C. S. (2018). Peralihan Hak Atas Tanah Tanpa Sertifikat. Jurnal Ilmu Hukum, 4 (2).

Ningrum, H. R. (2014). Analisis Hukum Sistem Penyelesaian Sengketa Atas Tahan Berbasis Keadilan. Jurnal Pembaharuan Hukum, 1 (2).

\section{Undang-Undang}

Undang-Undang Republik Indonesia Nomor 5 Tahun 1960 Tentang Peraturan Dasar PokokPokok Agraria. 